\title{
Prognostic of the Using Wood of Erythroxylum myrsinites Mart. Under the Anatomic Prism
}

\author{
Rossana Cortelini da Rosa ${ }^{1}$, Dione Dambrós Raddatz ${ }^{2}$, Paulo Fernando dos Santos Machado ${ }^{1}$, \\ Mario Lima dos Santos ${ }^{3}$, Alexandro Dias Martins Vasconcelos ${ }^{3}$, Walmer Bruno Rocha Martins ${ }^{4}$, \\ Larissa Martins Barbosa D'arace ${ }^{4}$, Anderson Marcos de Souza ${ }^{3}$, Cristiane Pedrazzi ${ }^{1} \&$ Darci Alberto Gatto ${ }^{5}$ \\ ${ }^{1}$ Federal Universit of Santa Maria, Santa Maria, Brazil \\ ${ }^{2}$ Embrapa Genetic Resources and Biotechnology, Brasília, Brazil \\ ${ }^{3}$ Universit of Brasilia, Brasília, Brazil \\ ${ }^{4}$ Federal Rural University of Para, Belém, Brazil \\ ${ }^{5}$ Federal University of Pelotas, Pelotas, Brazil
}

Correspondence: Dione Dambrós Raddatz, Embrapa Genetic Resources and Biotechnology, Av. W5 Norte (final), 70770-917 Brasília, DF, Brazil, Brazil. Tel: 55-55-99689-0707. E-mail: dionedambros@hotmail.com.br

Received: July 7, 2019

doi:10.5539/jas.v12n1p188
Accepted: September 3, $2019 \quad$ Online Published: December 15, 2019

URL: https://doi.org/10.5539/jas.v12n1p188

\begin{abstract}
The composition of the wood and its elements are considered determinants in the wood properties, standing out the fibers, axial parenchyma, number of vessels and rays. In this context, we aimed to investigate and describe the wood anatomical structure of the Erythroxylum myrsinites Mart. and identify its potential uses in the area of wood technology. From the tree, were removed three wood samples for the confection of anatomical slides, witch $3 \times 3 \times 3 \mathrm{~cm}$, oriented we plans transversal, longitudinal and tangential longitudinal. For the preparation of histological blades, the method of Burger and Richter was adopted; the anatomical description was based on IAWA Committee recommendations. The species presents vessels numerous, solitary, composing $19 \%$ of the volume of wood. Diffuse porosity of polygonal contour and thin walls. Mean vascular elements, axial parenchyma representing $3 \%$ of the volume of the wood, in a paratracheal vasicentric arrangement. The rays are numerous, occupying $23 \%$ of the volume of the wood, narrow and heterogeneous, consisting of procumbent, square and erect cells. The fibers are libriform, of length medium and thick walls, occupying $55 \%$ of the volume of the wood, have spiral thickening and septate fibers, absent tracheids, and gelatinous fibers abundant. The characteristics presented give high flexibility to the stem and branches, and the wood with low specific mass, permeable and resistant to mechanical loads has potential for use in energy generation.
\end{abstract}

Keywords: Erythroxylaceae, wood anatomy, wood technology, reophyte

\section{Introduction}

Historically, several researchers have sought to determine the relationship between the components of wood and the reflection of the anatomical composition on the properties of this material (Eames \& McDaniels, 1953; Burger \& Richter, 1991; Gomide, 2005; Marques, 2008). The anatomy of the wood provides a set of quantitative and qualitative data, which makes it possible to use it as a tool to help different areas of knowledge. It may present data such as the interaction between climatic conditions and plant growth (Olano et al., 2013; Castagneri et al., 2015), identification of species that are more resistant to climate change wood constitution and assistance in production and quality data (Cuny et al., 2015).

Currently, in the Brazilian scenario, the anatomy of wood has been attributed for the most part to descriptive aspects, i.e., to discover new species with potential for use mainly in the timber industry, relating anatomical data with physical, mechanical and even biological (Lima, 1994). That way a good knowledge of the anatomical properties of wood and its structures are essential for its application in wood technology. Wood properties-e.g., length and diameter of fibers, percentage and size of rays, and porosity — can determine its suitability and correct use (Denardi, 2007; Beeckman, 2016; Baldin et al., 2018). 
The most important anatomical characteristics that can determine the use of a species in wood technology are fibers, since they confer mechanical resistance to wood and, according to the authors Burger and Richter (1991) and Denardi (2007), can be affected by the arrangement of the axial parenchyma and by the percentage of rays. Another factor that affects mechanical resistance is the occurrence of reduced diameter pores and fibers with moderately thick walls (Lobão et al., 2004).

Almeida (2006) observed that the dimension of the vessels can affect the retraction of the wood, that is, species with elements of smaller vessels presented greater retraction factor and viceversa. In this context, we aimed to research and describe the wood anatomical structure of the Erythroxylum myrsinites Mart. and identify its potential use in the area of wood technology.

Our hypothesis is that the species E. myrsinites presents potential use of its wood. For this, we will quantify anatomical characters such as fibers, porosity diameter, vessels numbers and rays.

\section{Material and Methods}

\subsection{Study Site and Species}

Samples of E. myrsinites a rheophyte species were obtained from a forest remnant of the Atlantic forest domain, in the municipality of Farroupilha, Serrana Region, Rio Grande do Sul, Brazil (29 $23^{\prime} 29^{\prime \prime}$ S; 51 $23^{\prime} 43^{\prime \prime}$ W). The climate, according to the classification of Köppen is " $\mathrm{Cfb}$ " with average annual precipitation of $1837 \mathrm{~mm}$ and average annual temperature of $16.8^{\circ} \mathrm{C}$ (Tonet et al., 2014).

It is located at an average altitude of 770 meters with basaltic geological formation of Gramado type, mountainous relief and shallow soil (CPRM, 2010), classified as neosols (Embrapa, 2013). Was used an adult individual, approximately 5 meters high, outside the flowering/fruiting period, situated in a flood area on the banks of the river Antas.

\subsection{Preparaition of Wood Samples and Blades}

The region selected for anatomical transaction was at $1.3 \mathrm{~m}$ of height from the trunk of the tree chosen, and a 6-centimeter-thick wooden block was withdrawn four cubes of $3 \times 3 \times 3 \mathrm{~cm}$ in dimension were extracted from the chose wooden block. Three of these were used for the assembly of histological slides of the transverse longitudinal, tangencial and radial plans, and a fourth block was used for preparing slides of macerated.

The samples were boiled in water until absolute exclusion of air, softening for about 60 hours, and sectioned in sliding microtome at the Laboratory of Anatomia de Madeira, Federal University of Santa Maria. For mounting the anatomical slides, the standard methodology followed was the described by Burger and Richter (1991), and confectioned in slides with acrylic resin described by Paiva et al. (2006).

For macerated slides, a block was chipped and boiled in a test-tube with water for 2 hours. The maceration process followed the Jeffrey method (Freund, 1970) for observation and description of cell types. The coloration used was safranin, and acrylic with resin was prepared for the assembly of blades.

\subsection{Characterization and Descripition of the Wood}

The anatomical description of the wood characteristics of E. myrsinites was carried out to identify characteristics that may recognize possible uses of the species in wood technology. The description of the wood was based on the IAWA Committee (Wheeler et al., 1989).

The determination of the percentage of different tissues, width and height of the rays, as well as the wall thickness of fibers and vessels were obtained by random measurements using a laboratory meter after 600 random determinations, describe to Marchiori (1980). The images of the wood were obtained in a Photomicroscope DM 2000 equipped with digital camera (DFC 295).

\subsection{Statistical Analysis}

The data were checked for normality with the Shapiro-Wilk test and homogeneity with the Bartlett test, followed by analysis of variance (ANOVA) and comparison of means at $5 \%$ probability with the Tukey test. All analyzes were performed using SISVAR statistical software v5.6 (Ferreira, 2014).

\section{Results and Discussion}

Vessels of Erythroxylum myrsinites were numerous, solitary, trivially twinned, and represented $19 \%$ of the total volume of the wood. They presented diffuse porosity, polygonal contour and thin walls. Medium-sized vascular elements $(364 \mu \mathrm{m})$ were characterised by simple perforation plates disposed obliquely, and presented short appendages at one end (Figure 1). 
The axial parenchyma represented $3 \%$ of the wood volume and it appeared in an incomplete vasocentric paratracheal arrangement, occasionally aliform or confluent aliform. Scarce paratracheal and marginal bands characterised the limit of the growth rings. Parenchyma series wich the $415 \mu \mathrm{m}$ in height and 3 to 7 cells (Figure 1A, B). Rhombohedral crystals are presented in series, visualized also in the cross section.

Numerous narrow and heterogeneous rays, consisting of procumbent, square and upright cells (Figures $1 \mathrm{C}$ and 1D) represented $23 \%$ of the volume of the wood. Rays were mainly bisseriate (47\%) and less frequently triseriate $(28 \%)$ and unisseriate $(25 \%)$. Radial cells presented a rounded circumference were disposed in tangential plane, while enveloping cells were arranged radially, and presented separated walls and fused rays. Fibers were libriformes of medium length (Table 1) and of $11 \mu \mathrm{m}$ width on average. They had thick walls $(3.6 \mu \mathrm{m})$ and constituted $55 \%$ of the wood volume. With spiraled thickenings, and septate fibers, characterised by the absence of tracheids and an abundance of gelatinous fibers (Figures $1 \mathrm{E}$ and $1 \mathrm{~F}$ ).
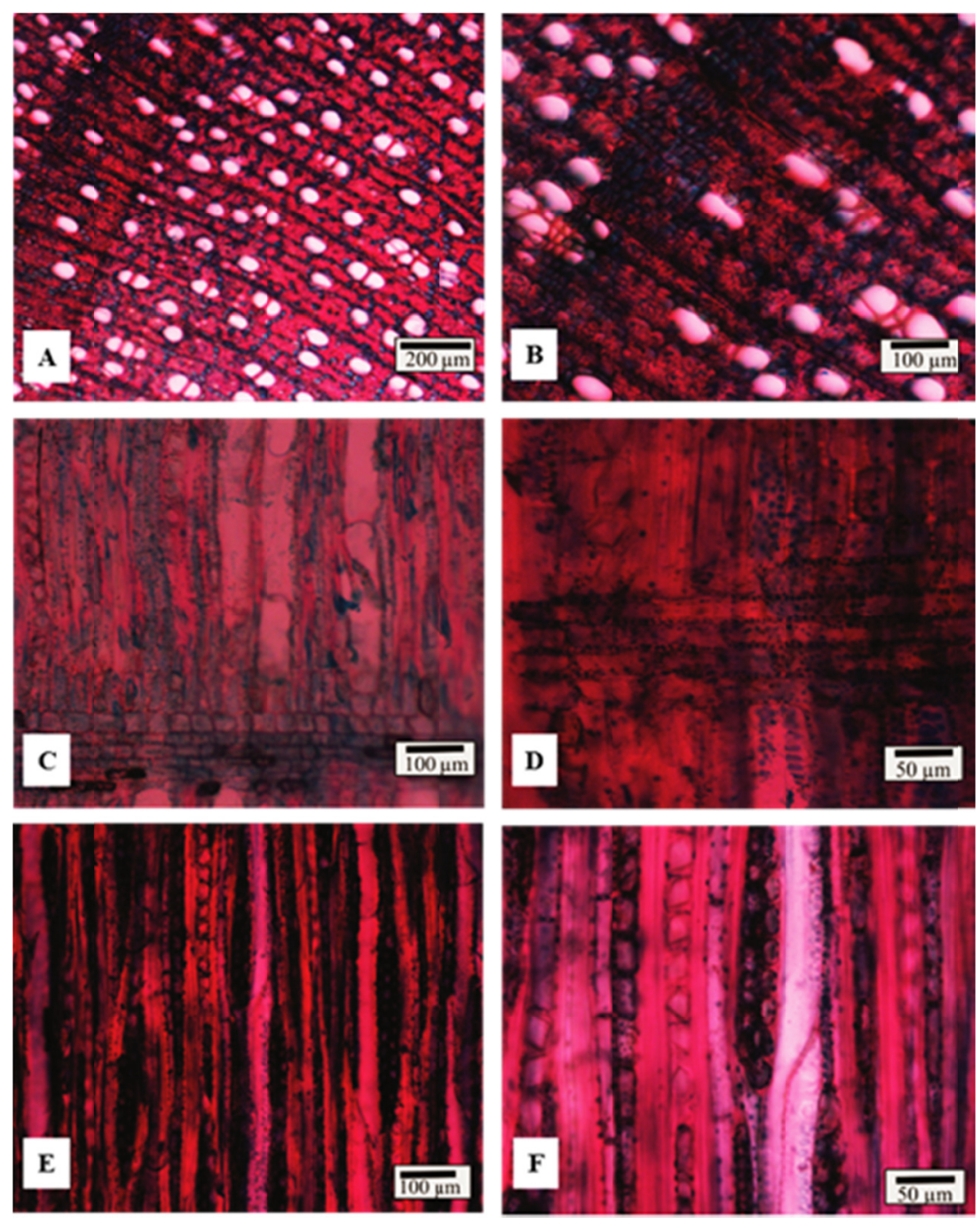

Figure 1. Photomicrographs the anatomy of the wood of Erythroxylum myrsinites: (A, B) Diffuse porosity, solitary pores and in radial multiples and axial parenchyma; (C, D) Simple perforate plates and cells of square and erect rays; (E, F) Rays and gelatinous fibers

The anatomical structure of wood did not differ among samples with the only exception of fibers that showed significant difference between the samples number three compared to one two samples, where it showed a higher number of fibers, 1084 (Table 1). 
Table 1. Quantitative values referring to the anatomical characteristics of the Erythroxylum myrsinites wood

\begin{tabular}{llll}
\hline Anatomical characteristics & Sample no. 1 & Sample no. 2 & Sample no. 3 \\
\hline Vessel number $\mathrm{mm}^{-2}$ & $208_{\mathrm{a}}$ & $223_{\mathrm{a}}$ & $215_{\mathrm{a}}$ \\
Pore diameter $(\mu \mathrm{m})$ & $31_{\mathrm{a}}$ & $35_{\mathrm{a}}$ & $32_{\mathrm{a}}$ \\
Ray number $\mathrm{mm}^{-2}$ & $23_{\mathrm{a}}$ & $24_{\mathrm{a}}$ & $26_{\mathrm{a}}$ \\
Fibre length $(\mu \mathrm{m})$ & $915_{\mathrm{b}}$ & $901_{\mathrm{b}}$ & $1084_{\mathrm{a}}$ \\
\hline
\end{tabular}

Note. Average followed by the same letter not differ Tukey test at the level of $5 \%$ error probability.

In comparison, the three samples do not differ in the anatomical structure of wood, with the exception of the number of fibers, where there was significant difference. The fibers are the predominant character of the anatomical structure of the tree occupying $55 \%$ of volume of wood.

From a technological viewpoint, the fibers are the cellular elements have a greater influence in the wood, since the quantification of the elements that compose the wood and its structure are of extreme importance in the designation of the wood use (Paula et al., 2000). Thus, because high percentage the fibers and low proportion of the axial parenchyma, the wood of E. myrsinites once subjected to carbonization produces quality charcoal, and it can be used the energy acquisition, since these characters are sources of support of the combustion.

This can be evidenced by studies conducted by Baldin et al. (2018), where they emphasize the fibers produce a greater quantity of substances like lignin, cellulose, hemicelluloses, and these are associated to the generation of energy. Another use that can be attributed to wood of E. myrsinites is the production of pulp and paper.

Different properties, both anatomical and chemical, are necessary for the production of cellulose and paper, which emphasize the percentage of fibers in the wood, as well as its length and width (Campos et al., 2000), once characters allow to presume the behavior of the pulping process in manufacturing activities.

E. myrsinites has quite narrow vessels with thin walls; feature marked in rheophyte species, a group created by Van Steenis (1981) which have high flexibility of their stems and branches. Another striking feature of the group is the abundant presence of gelatinous fibers which confers flexibility to the wood.

The structure of the wood is typical of the genus Erythroxylum, which diffuse porosity of polygonal contour and thin walls, mean vascular elements with simple, oblique perforation plates of short appendages (Record \& Hess, 1943; Metcalfe \& Chalk, 1972; Raddatz et al., 2018). Given the high percentage thick-walled fibers, their wood can be indicated for different uses, the most relevant being the generation of energy, such as coal or firewood.

\section{Conclusions}

The species Erythroxylum myrsinites it has anatomical characteristics infer the wood low specific mass, and resistance to mechanical stresses. Its wood can be used production of pulp and paper and the generation of energy. However, for effective use in wood technology, it physical and chemical characteristics should be researched through specific tests.

\section{Acknowledgements}

CAPES (Coordenação de Aperfeiçoamento de Pessoal de Nível Superior) and CNPq (Conselho Nacional de Desenvolvimento Científico e Tecnológico) for financial support.

\section{References}

Almeida, A. N. (2006). Estudo econométrico da demanda e oferta de madeira em tora para o processamento mecânico no estado do Paraná (235f., Dissertação (Mestrado em Ciências Florestais), Universidade Federal do Paraná, Brazil).

Baldin, T., Talgatti, M., Marchiori, J. N. C., \& Silveira, A. G. (2018). Previsões tecnológicas na madeira de quatro folhosas neotropicais: Uma análise sob enfoque anatômico. Nativa, 6(1), 107-112. https://doi.org/ 10.31413/nativa.v6i1.4738

Beeckman, H. (2016). Wood anatomy and trait-based ecology. IAWA Journal, 37(2), 127-151. https://doi.org/ $10.1163 / 22941932-20160127$

Burger, L. M., \& Richter, H. G. (1991). Anatomia da Madeira (p. 154). São Paulo: Ed. Nobel.

Campos, E. S., Martins, M. A. L., Foelkel, C. E. B., \& Frizzo, S. M. B. (2000). Seleção de critérios para a especialização de pastas branqueadas de eucalipto na fabricação de papéis para impressão offset. Ciência Florestal, 10(1), 57-75. https://doi.org/10.5902/19805098395 
Castagineri, D., Petit, G., \& Carrer, M. (2015). Divergent climate response on hydraulic-related xylem anatomical traits of Picea abies along a 900-m altitude in al gradient. Tree Physiol, 35, 1378-1387. https://doi.org/10.1093/treephys/tpv085

CPRM (Companhia de Pesquisas e Recurso Minerais). (2010). Mapa Geológico do Estado do Rio Grande do Sul (p. 254). Secretaria de Geologia, Mineração e Transformação Mineral. Ministério de Minas e Energia. Serviço Geológico do Brasil.

Cuny, H. E., Rathgeber, C. B. K., Frank, D., Fonti, P., Mäkinen, H., Prislan, P., ... Fournier, M. (2015). Woody biomass production lags stem-girth increase by over one month in coniferous forests. Nature Plants, 1, 1-6. https://doi.org/10.1038/nplants.2015.160

Denardi, L. (2007). Anatomia e flexibilidade do caule de quatro espécies lenhosas para o manejo biotécnico de cursos de água (113f., Tese (Doutorado em Manejo Florestal), Universidade Federal de Santa Maria, Brazil).

Eames, A. J., \& McDaniels, L. H. (1953). An introduction to Plant Anatomy (p. 427). Bombay: New Dehli.

Embrapa (Empresa Brasileira de Pesquisa Agropecuária). (2013). Sistema brasileiro de classificação de solos (p. 353). Brasília, Brazil.

Ferreira, D. F. (2014). Sisvar: A guide for its bootstrap procedures in multiple comparisons. Ciênc. Agrotec., 38(2), 109-112. https://doi.org/10.1590/S1413-70542014000200001

Freund, H. (1970). Handbuch der Mikroskopie in der Technik (p. 375). Frankfurt: Umsham Verlag.

Gomide, L. J., Colodette, L. J., Oliveira, C. R., \& Silva, M. C. (2005). Caracterização tecnológica, para a produção de celulose, da nova geração de clones de Eucalyptus do Brasil. Revista Árvore, 29(1), 129-137. https://doi.org/10.1590/S0100-67622005000100014

Lima, M. R. (1994). Anatomia comparada do lenho de quatro espécies de Guarea Allamand ex. Linnaeus ocorrentes na Zona da Mata Mineira e na Amazônia Brasileira (95f, Dissertação (Mestrado em Engenharia Florestal), Universidade Federal de Viçosa, Brazil).

Lobão, M. S., Della Lúcia, R. M., Moreira, M. S. S., \& Gomes, A. (2004). Caracterização das propriedades físico-mecânicas da madeira de eucalipto com diferentes densidades. Revista Árvore, 28(6), 889-894. https://doi.org/10.1590/S0100-67622004000600014

Marchiori, J. N. C. (1980). Estudo anatômico do xilema secundário de algumas espécies dos gêneros Acacia e Mimosa, nativas no estado do Rio Grande do Sul (186f., Dissertação (Mestrado em Engenharia Florestal), Universidade Federal do Paraná, Curitiba).

Marques, M. H. (2008). Agrupamento de 41 espécies da Amazônia para secagem baseado em características anatômicas e físicas (125f., Tese (Doutorado em Engenharia Florestal), Universidade de Brasília, Brazil).

Metcalfe, C. R., \& Chalk, L. (1972). Anatomy of the Dicotyledons (p. 1500). Oxford: Clarendon Press.

Olano, J. M., Arzac, A., Gárcia-Cervigón, A. I., Von Arx, G., \& Rozas, V. (2013). Amount of ray parenchyma in tree rings shows a link to climate. New Phytol, 198, 486-495, https://doi.org/10.1111/nph.12113

Paiva, J. A., Fank-de-Carvalho, S. M., Magalhães, M. P., \& Graciano-Ribeiro, D. (2006). Verniz vitral incolor 500R: Uma alternativa de meio de montagem economicamente viável. Acta Botanica Brasilica, 20(2), 257-264. https://doi.org/10.1590/S0102-33062006000200002

Paula, J. E., Silva Júnior, F. G., \& Silva, A. P. P. (2000). Caracterização anatômica de madeiras nativas de matas ciliares do centro-oeste brasileiro. Scientia Florestalis, 58, 73-89.

Raddatz, D. R., Machado, P. F. S., Rosa, R. C., Sousa, R. S., Sutili, F. J., \& Marchiori, J. N. C. (2018). Anatomia do Lenho de Erythroxylum substriatum. Balduinia, 62, 27-32. https://doi.org/10.5902/2358198033224

Record, S. J., \& Hess, R. W. (1943). Timbers of the New World (p. 640). New Haven: Yale Univ. Press.

Tonet, E. M., Pergher, R., Oliveira, R. E. G. de, \& Maino, T. (2014). Plano Municipal de Saneamento Básico (p. 267). Secretaria Municipal de Meio Ambiente, Farroupilha, RS.

Van Steenis, C. G. G. L. (1981). Rheophytes of the World. An account of the flood resistant flowering plants and ferns and the theory of autonomous evolution. Netherlands: Sijthoff \& Noordhopp. https://oi.org/10.1007/ 978-94-009-8588-9 
Wheeler, E. A., Baas, P., \& Gasson, P. E. (1989). IAWA list of microscopic features for hardwood identification. IAWA Bulletin, 10(3), 218-359. https://doi.org/10.1163/22941932-90000496

\section{Copyrights}

Copyright for this article is retained by the author(s), with first publication rights granted to the journal.

This is an open-access article distributed under the terms and conditions of the Creative Commons Attribution license (http://creativecommons.org/licenses/by/4.0/). 